\title{
Scoping Calculations for Potential Groundwater Impacts from Operation of the APT Facility at SRS
}

by

J. J. Thibault

Westinghouse Savannah River Company

Savannah River Site

Aiken, South Carolina 29808

D. E. Stephenson

J. Roberts

This paper was prepared in connection with work done under the above contract number with the $U$. $S$.

Department of Energy. By acceptance of this paper, the publisher and/or recipient acknowledges the U. S.

Government's right to retain a nonexclusive, royalty-free license in and to any copyright covering this paper, along with the right to reproduce and to authorize others to reproduce all or part of the copyrighted paper. 


\section{DISCLAIMER}

This report was prepared as an account of work sponsored by an agency of the United States Government. Neither the United States Government nor any agency thereof, nor any of their employees, makes any warranty, express or implied, or assumes any legal liability or responsibility for the accuracy, completeness, or usefulness of any information, apparatus, product, or process disclosed, or represents that its use would not infringe privately owned rights. Reference herein to any specific commercial product, process, or service by trade name, trademark, manufacturer, or otherwise does not necessarily constitute or imply its endorsement, recommendation, or favoring by the United States Government or any agency thereof. The views and opinions of authors expressed herein do not necessarily state or reflect those of the United States Government or any agency thereof.

This report has been reproduced directly from the best available copy.

Available to DOE and DOE contractors from the Office of Scientific and Technical Information, P.O. Box 62, Oak Ridge, TN 37831; prices available from (615) 576-8401.

Available to the public from the National Technical Information Service, U.S. Department of Commerce, 5285 Port Royal Road, Springfield, VA 22161. 


\section{DISCLAIMER}

Portions of this document may be illegible in electronic image products. Images are produced from the best available original document. 


\section{WSRC-TR-99-00373}

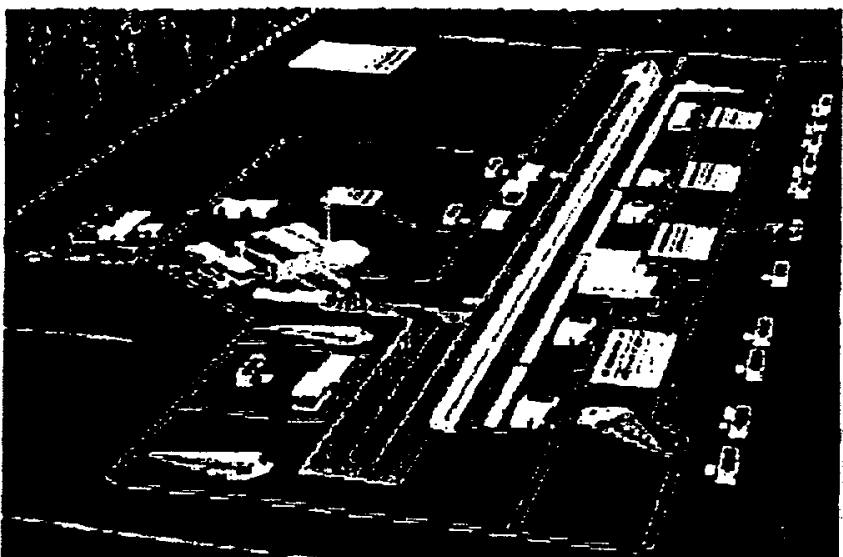

SCOPING CALCULATIONS

FOR POTENTIAL GROUNDWATER IMPACTS

FROM OPERATION OF THE

\section{ACCELERATOR PRODUCTION OF TRITIUM (APT) FACILITY}

AT SAVANNAH RIVER SITE, SC

J. J. Thibault

D. E. Stephenson

Site Geotechnical Services Department WSRC/BSRI 


$$
W S R C-T R-99-00373
$$

\section{TABLE OF CONTENTS}

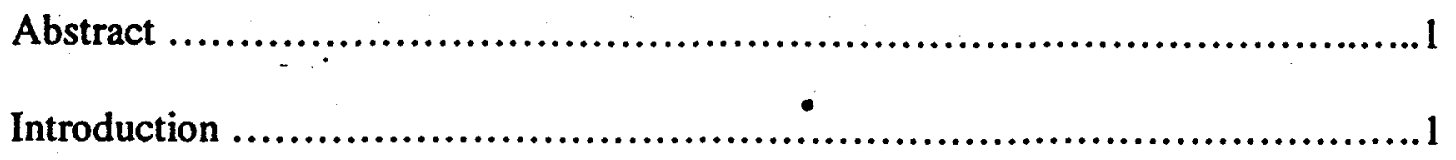

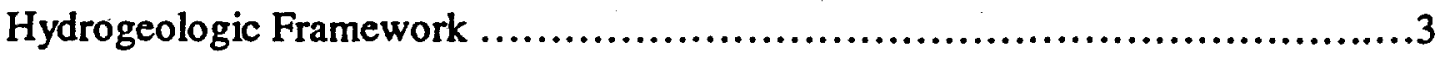

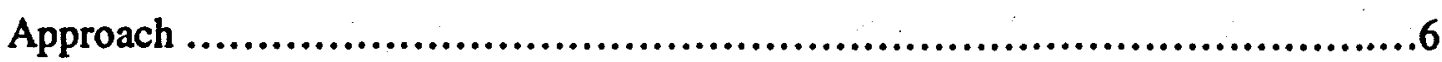

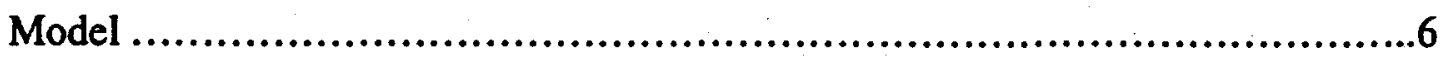

Model Calibration .............................................................. 7

Results

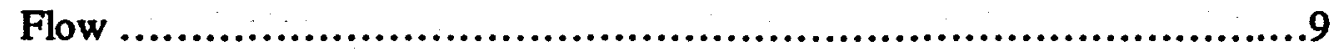

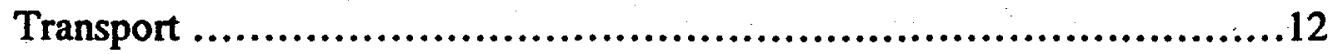

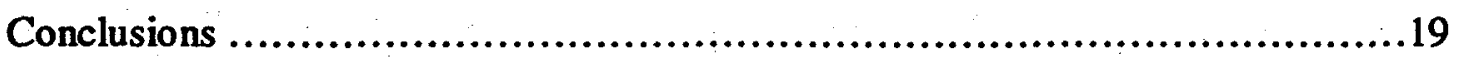

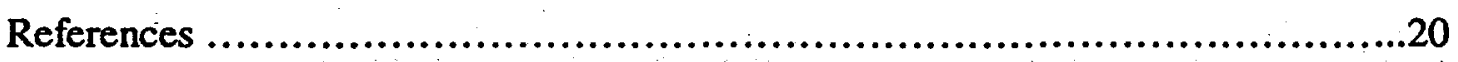

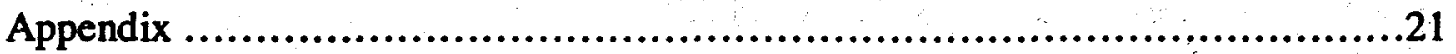

\section{LIST OF TABLES}

I. Initial estimates of aquifer properties assigned to numerical model ..........7

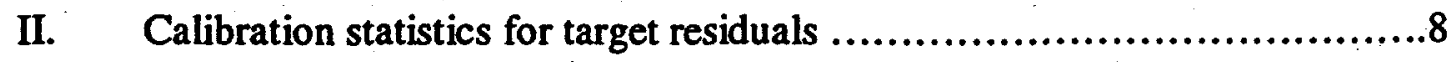

III. Initial and calibration hydraulic conductivity for the flow model ...........9

\section{LIST OF FIGURES}

1 Potential location of the Accelerator Production of Tritium facility at the Savannah River Site, South Carolina ...............................................2

2 Geologic section of the watertable aquifer at the APT site based on a model of the friction ratio as determined using the cone penetrometer .....................5

3 Geologic map of the McQueen Branch-Mill Creek Divide (Prowell 1996) .......5

4 Measured head versus model calculated head for calibration targets ............8 


\section{LIST OF FIGURES (Continued)}

5 Upper Three Runs simulated water table and flow paths ......................10

6 Gordon Aquifer simulated potentiometric map and flow paths ..................11

7 Tritium concentrations at modeled monitoring wells .........................13

8 East-west profile through the target blanket building showing simulated tritium activation after 40 years of operation ........................................14

9 East-west profile 732 meters north of the target building showing simulated tritium activation after 40 years of operation .................................15

10a,b Simulated extent of future tritium activation after 40 years of operation based on an activation source of $1.56 \mathrm{e}+4 \mathrm{pCi} / \mathrm{l}$, Upper Three Runs Aquifer, Gordon Confining Unit

11 Simulated extent of future tritium activation after 40 years of operation based on an activation source of $1.56 \mathrm{e}+4 \mathrm{pCil}$, Gordon Aquifer .....................17

12 Simulated extent of future tritium activation after 40 years of operation based on an increased activation source of $2.0 \mathrm{e}+5 \mathrm{pCi} / 1$ 


\section{WSRC-TR-99-00373}

\section{ABSTRACT}

The McQueen Branch-Mill Creek Divide has been designated as the preferred potential location for the proposed Accelerator Production of Tritium (APT) facility at the Savannah River Site (SRS), South Carolina. This area is underlain by approximately $91.4 \mathrm{~m}$ (300 ft) of Tertiary age unconsolidated sand, clay, and calcareous deposits, which comprise two aquifers and two aquitards. A three-dimensional, steady state, numerical model representing the Tertiary aquifer system was constructed to predict potential travel times and paths of the activation products in the groundwater.

The numerical model encompasses an area of approximately $30.3 \mathrm{~km}^{2}\left(11.7 \mathrm{mi}^{2}\right)$. The model has a uniform (61 m by $61 \mathrm{~m}$ (200 ft by $200 \mathrm{ft})$ ), block centered finite difference grid which consists of 100 rows, 82 columns, and 3 layers. The model was calibrated to target values defined for 39 wells in the model area, based on visual and statistical evaluations of simulated and measured heads. Calibrated aquifer properties were in close agreement with those reported in the existing literature for the hydrogeologic units simulated.

Based on water budget analysis, inflow to the system is primarily via recharge to the surficial aquifer, while ground-water discharge is to Tinker Creek, the primary ground-water sink. Particle tracking analysis indicates that non-reactive particles released to the water table in the vicinity of the proposed APT facility generally flow to the northwest and discharge to Tinker Creek. Based on particle tracking, the travel time for particle transport from source to surface discharge ranges from 80 to 175 years. This range is necessary due to the uncertainties of the numerical representation resulting from the limited data available.

Additional modeling was performed to evaluate the fate and transport of tritium in the groundwater produced by actiyation beneath the target blanket building at the proposed APT. Tritium generation was represented as a continuous unit recharge source (approximated to be $10,000 \mathrm{pCi} / \mathrm{V} / \mathrm{yr}$ ) applied to the water table for a period of 40 years. Predictive modeling using advective transport suggests that tritium concentrations are low and should remain below drinking water standards at 3 simulated monitoring points downgradient of the activation source. The transport modeling results indicate that it is unlikely that tritium will be discharged to nearby surface streams within the 40 year operational life of the APT.

\section{INTRODUCTION}

The U.S. Department of Energy made a programmatic decision that the maintenance of the current weapons stockpile requires the development of a new weapons grade tritium, a gaseous radioactive isotope of hydrogen, production source. It was stated that this action will ensure that this production source will present the least possible impact to the environment. The McQueen Branch-Mill Creek Divide located in the central portion of the Savannah River Site (SRS) in South Carolina has been designated as the preferred potential location for the Accelerator Production of Tritium facility (Figure 1).

Because tritium has a relatively brief half-life (12.3 years), a new supply must become available by 2006 - based on current projections - to ensure that national defense 


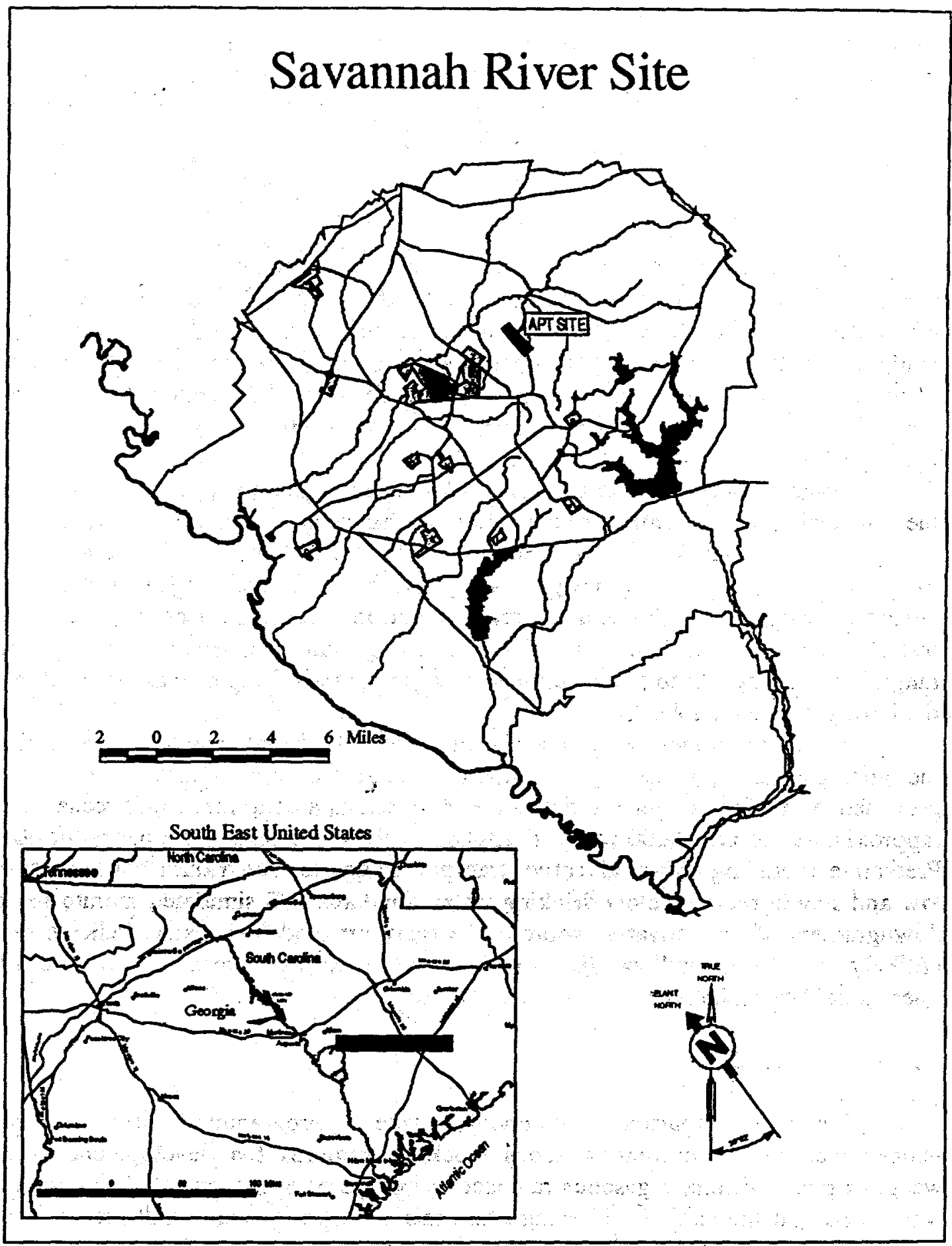

Figure 1 Potential location of the Accelerator Production of Tritium facility at the Savannah River Site, South Carolina. 


$$
\text { WSRC - TR-99-00373 }
$$

needs are met. Several alternatives for the production of tritium have been explored, including construction of a New Production Reactor (NPR) at SRS. The NPR, initially the technology of choice, later was canceled.

Production of tritium in sufficient quantities can be accomplished only through neutron capture by a stable isotope, such as helium-3 (He-3) or lithium-6 ( $\mathrm{Li}-6)$. In an accelerator, these neutrons are produced from the high-speed collision of protons with heavy-metal nuclei, such as tungsten.

To produce tritium, the APT would use a high-powered linear accelerator to generate neutrons. The neutrons would be thermalized and captured by Helium-3 to yield tritium, which would be separated and purified to yield weapons grade material.

As required by the DOE, the APT is designed to safely produce sufficient quantities of tritium to meet national defense needs. The performance criteria for the APT is to (1) produce up to 3 kilograms of tritium annually; (2) have an operational lifetime of 40 years; (3) minimize public and worker exposure to radiological, nonradiological, toxic, and other hazardous materials and conditions according to DOE and other regulatory requirements; (4) meet DOE security-and-safeguards standards for accountability of tritium; and (5) reduce capital and operating costs with minimum technical risk.

The purpose of this study was to determine the potential travel times and paths of the postulated activated groundwater beneath the facility and to examine the fate and transport of this activated groundwater. The study consisted of two phases; the first was to model the flow to determine velocity, travel times, and possible flow paths within the existing ground-water system. The second phase was to perform transport modeling to estimate tritium concentration at downgradient boundaries to provide estimates of the potential exposure to the environment during 40 years of operation estimated for the APT facility.

\section{HYDROGEOLOGIC FRAMEWORK}

The study area is located within the SRS in the updip portion of the Atlantic Coastal Plain, approximately $32.2 \mathrm{~km}(20$ miles) southeast of the Fall Line. The SRS is underlain by a southeast thickening wedge of unconsolidated to poorly consolidated Late Cretaceous and Tertiary sand, clay, and calcareous sediments, which are from $198.1 \mathrm{~m}$ $(650 \mathrm{ft})$ to $426.7 \mathrm{~m}$ (1400 ft) thick (Fallaw (1995)). Deposition occurred during a series of transgressions and regressions, and depositional environments ranged from fluvial to marine and shallow marine. The Upper Cretaceous sediments nonconformably overlie Paleozoic igneous and metamorphic basement rocks and Triassic red beds.

This investigation focuses on the shallow hydrogeologic system comprised of the Tertiary sediments, as these shallow aquifers are more likely to be impacted by site development than the deeper aquifers. Locally these sediments are approximately $91.4 \mathrm{~m}$ ( $300 \mathrm{ft}$ ) thick and dip to the southeast at $3.41 \mathrm{~m} / \mathrm{km}$ (18 ft/mile). This system is divided into two aquifer units and two confining units on the basis of lithology and hydraulic characteristics.

The stratigraphy used in this study is modified from that of Fallaw and Price (1995) and the hydrostratigraphy is taken from Aadland et. al (1995). The hydrostratigraphic units are, from shallowest to deepest, the Upper Three Runs Aquifer 
(UTRA), the Gordon Confining Unit (GCU), the Gordon Aquifer (GA), and the Crouch Branch Confining Unit (CBCU).

The UTRA is the primary water table aquifer at the study area and consists of medium to coarse, muddy quartz sands with few thin clay laminae present throughout the formation. The-hydraulic conductivity measured from pumping tests and slug tests ranges from 1.22 to $3.96 \mathrm{~m} /$ day ( 4 to $13 \mathrm{ft} /$ day). The average depth to the water table is $16.8 \mathrm{~m}$ $(55 \mathrm{ft})$. Recharge to this unit is primarily via infiltration of rainwater at the surface and is estimated by a separate study to be approximately $0.15 \mathrm{~m} / \mathrm{yr}(6 \mathrm{in} / \mathrm{yr})$ (Aadland 1995).

The GCU serves to fully confine the GA and is laterally continuous across the study area. At the core of this unit is a low permeability "green clay" unit. This clay section comprises approximately $1.8 \mathrm{~m}(6 \mathrm{ft})$ of the GCU while the entire thickness

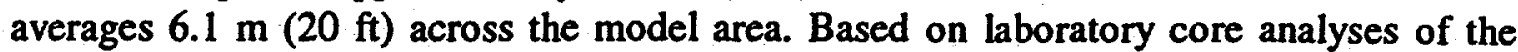
$\mathrm{GCU}$, the average effective vertical hydraulic conductivity is $3.96 \mathrm{e}-5 \mathrm{~m} /$ day $(1.3 \mathrm{e}-4$ $\mathrm{ft} /$ day).

The GA is the primary water-bearing unit within the Tertiary section and is composed of approximately $24.38 \mathrm{~m}$ (80 ft) of clean, medium- to coarse-grained, moderately- to well-sorted quartz sand. The average hydraulic conductivity of this unit is significantly greater than that of the overlying aquifer, and is estimated to be $9.14 \mathrm{~m} /$ day ( $30 \mathrm{ft} /$ day) from pumping test results. In general, the unit is fully confined across the study area, except where it has been incised by Tinker Creek along the northern boundary of the Divide.

The CBCU forms the base of the Tertiary hydrologic system and is assumed to be

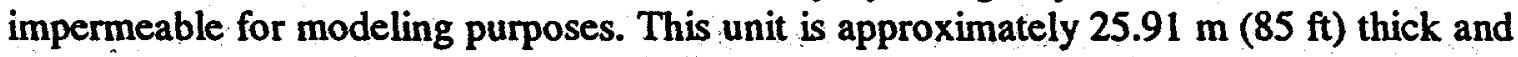
is composed of thick clays and clayey sands. The natural vertical gradient across this unit is very low, 0.11 to 0.05 measured across the model area.

The depth to the water table surface averages $12 \mathrm{~m}(39.4 \mathrm{ft})$ below the ground surface at the south end of the proposed facility to about $18 \mathrm{~m}(59.1 \mathrm{ft})$ at the northern end. The water table aquifer discharges into Tinker Creek to the north of the site and to the northeast to a tributary of Tinker Creek, Mill Creek. The movement of the ground water within the water table aquifer tends to follow the surface topography to the nearby surface streams. The heterogeneous nature of the water table aquifer (Figure 2) affects the local movement of the groundwater.

A prominent downward gradient results in the water within the upper most aquifer moving down into the first confined aquifer through the upper confining unit. Below the proposed facility the groundwater flow within the GA, the first confined aquifer, is toward the northwest where it discharges to Tinker Creek.

Site topography is characterized by a drainage divide bounded by high relief stream valleys (see Figure 3). The northern portion of the site contains steep escarpments where streams have eroded deep into the sediments. Surface drainage is via overland flow to the tributaries of McQueen Branch, Mill Creek, Tinker Creek, and Fourmile Branch, the four primary streams bounding the divide. 


\section{WSRC-TR-99-00373}

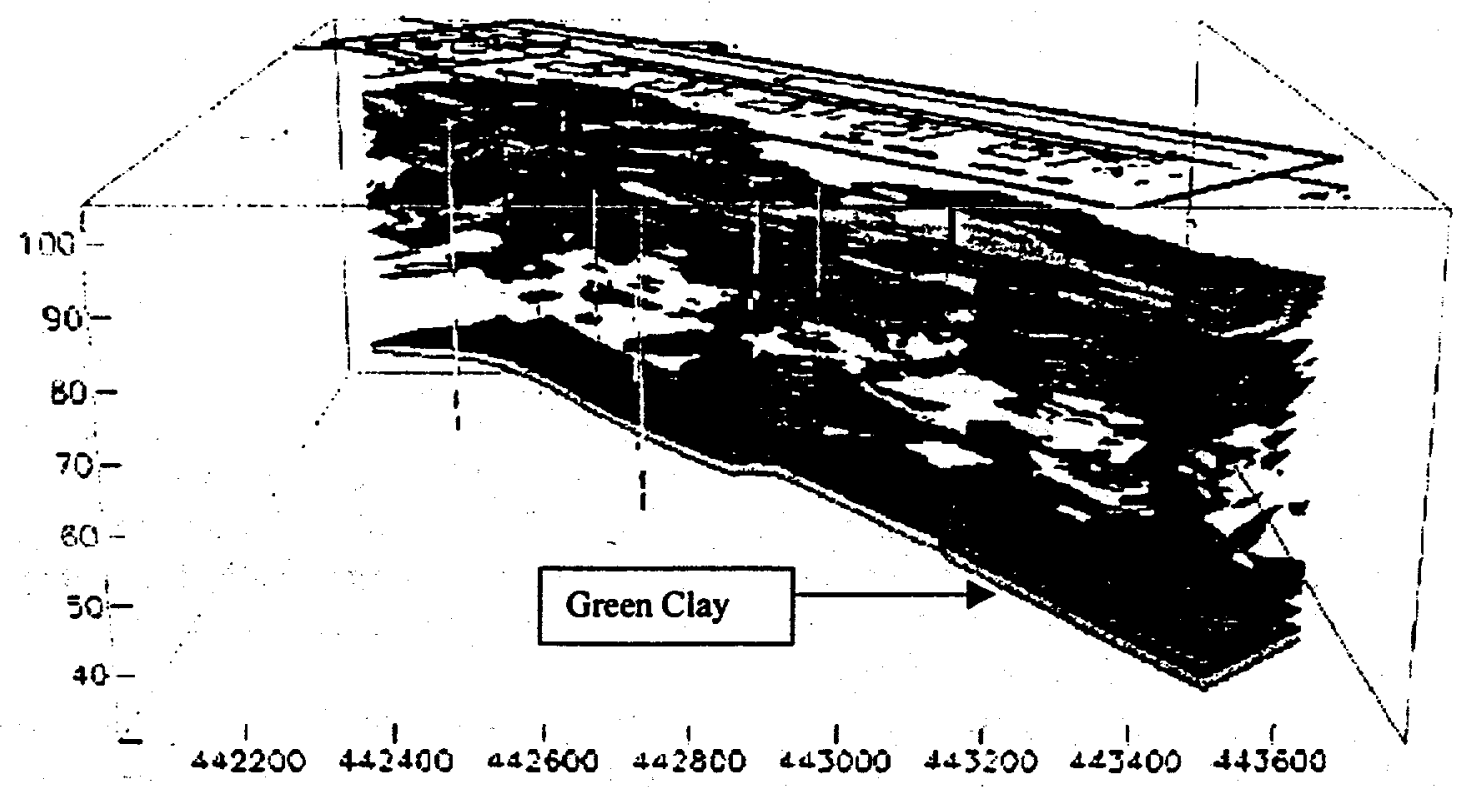

Figure 2 Geologic section of the water table aquifer at the APT Site based on a model of the friction ratio as determined using the cone penetrometer. Ratio values between 3 and 10 are shown. Generally speaking lighter colors and greater ratio values indicate higher fines content. Existing wells located within the APT footprint are also visible.

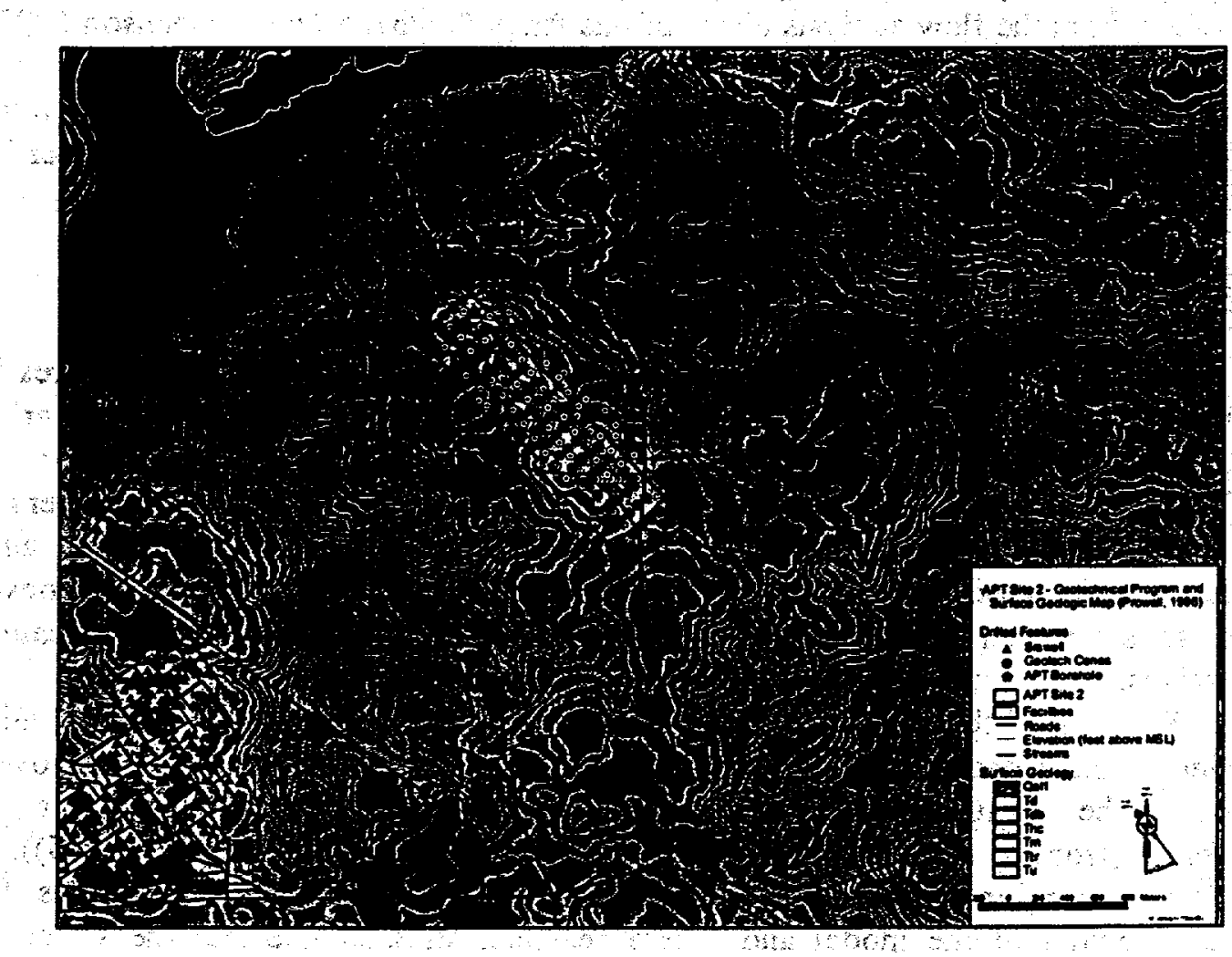

Figure 3 Geologic map of the McQueen Branch-Mill Creek Divide (Prowell 1996). 


\section{APPROACH}

The primary objective of this study was to predict the direction of and potential tritium concentration levels at postulated down gradient compliance points from activation of the groundwater below the Target Blanket Building. These modeling results would then provide guidance as to the potential for impact to the environment due to the operation of the facility.

The modeling approach for the APT consisted of using the flow paths determined from flow modeling to locate postulated compliance points and then perform transport calculations to model concentrations from facility operations.

Based on engineering design parameters, it was assumed that the tritium loading of the groundwater due to activation would amount to $10,000 \mathrm{pCi} / \mathrm{l} / \mathrm{yr}$ over an area $20 \mathrm{~m}$ $(65 \mathrm{ft})$ in diameter and approximately $0.5 \mathrm{~m}(1.5 \mathrm{ft}$ ) in depth (J. England, Personal Communication). It was also assumed that the base of the target blanket building was below the surface of the water table. This will result in a total activity of $1.57 \times 10^{9} \mathrm{pCi} / \mathrm{yr}$ in the groundwater below the facility.

Steady-state numerical simulations of the ground-water flow were performed using Groundwater Vistas (Rumbaugh (1995) and the U. S. Geological Survey MODFLOW code (McDonald and Harbaugh (1988))) to evaluate flow directions and velocities. Particle tracking (U. S. Geological Survey MODPATH code) was also performed to predict travel times and directions associated with advective transport.

The three-dimensional finite difference code MODFLOWT (Duffield et al, 1997) was used in the contaminant transport analysis of this study. The flow portion of the contaminant transport modeling was reproduced using the input parameters and calibration from the flow analysis phase of this study (Thibault and Stephenson 1998).

In order to examine the potential tritium concentrations in what might be considered the worst case, steady-state conditions were assumed even though a transient state exists. The tritium loading was assumed to remain constant over the 40 -year life of the facility.

\section{MODEL}

The model area and approximate location of the APT are shown in Figures 5 and 6. A uniform $61 \mathrm{~m}$ by $61 \mathrm{~m}$ ( $200 \mathrm{ft}$ by $200 \mathrm{ft}$ ), block centered finite difference grid was oriented to account for the geometry of the area. The model grid consists of 100 rows and 82 columns covering an area of approximately $30.3 \mathrm{~km}^{2}\left(11.7 \mathrm{mi}^{2}\right)$. Three layers were used to represent the Upper Three Runs Aquifer, the Gordon Confining Unit, and the Gordon Aquifer, model layers 1,2, and 3 respectively. The model structure was designed to be as simplified as possible, yet retain sufficient detail to provide meaningful estimations.

The top of the hydrologic system is represented by the water table, which is contained almost entirely within model layer 1 , except where it has been removed by erosion in the stream channels. The lateral extent of the water table in layer 1 was determined from a regional water table map of the area (Hiergesell (1995)). This boundary is represented in the north half of the model using constant head cells. In the southern portion of the model and where seasonal streams intersect the water table, 


$$
\text { WSRC-TR-99.00373 }
$$

surface drain cells representing the streams and tributaries are used to bound the system. Drain node elevations were specified using surface elevations from U. S. Geological Survey 7.5-minute quadrangle maps. A small segment of the western and southern boundaries between Fourmile Branch and the head waters of McQueen Branch and Mill Creek was defined as a no flow boundary, as were the lateral bounds of the Gordon Confining Unit and the base of the Gordon Aquifer. The Gordon Aquifer was bounded laterally using constant head cells to represent the potentiometric surface, as determined from a regional potentiometric map for the Gordon Aquifer (Aadland (1995)). This approach was necessary due to the lack of site specific potentiometric data available for the Gordon Aquifer.

Initial estimates of aquifer and confining unit hydraulic properties were obtained from a limited number of aquifer performance tests and laboratory analyses conducted for this area as shown in Table I. Drain cell conductance was assigned sufficiently high values $\left(306.6 \mathrm{~m}^{2}\right.$ to $800 \mathrm{~m}^{2} /$ day ( $3300 \mathrm{ft}^{2}$ to $8611 \mathrm{ft}^{2} /$ day)) so as not to restrict groundwater flow to the boundary. This range of conductance was necessary to account for the variation in stream length per cell, assuming all other factors are constant.

Table I. Initial estimates of aquifer properties assigned to numerical model.

\begin{tabular}{|c|c|c|c|c|c|}
\hline $\begin{array}{l}\text { Model } \\
\text { Layer }\end{array}$ & $\begin{array}{l}\text { Hydraulic } \\
\text { Conductivity } \\
\text { (m/day) }\end{array}$ & $\begin{array}{c}\text { Leakance } \\
\text { (1/day) }\end{array}$ & $\begin{array}{l}\text { Recharge } \\
\text { (m/day) }\end{array}$ & Porosity & $\begin{array}{l}\text { Storage } \\
\text { Coefficient }\end{array}$ \\
\hline 1 & $\begin{array}{l}K x=9.1 \mathrm{e}-1 \\
K y=9.1 \mathrm{e}-1 \\
\mathrm{Kz}=9.1 \mathrm{e}-2\end{array}$ & $1.0 \mathrm{e}-2$ & $6.2 \mathrm{e}-4$ & 0.3 & $\begin{array}{l}S=5.0 \mathrm{e}-4 \\
S y=2.5 \mathrm{e}-1\end{array}$ \\
\hline 2 & $\begin{array}{l}\mathrm{Kx}=4.6 \mathrm{e}-5 \\
\mathrm{Ky}=4.6 \mathrm{e}-5 \\
\mathrm{Kz}=4.6 \mathrm{e}-5\end{array}$ & $1.0 e-2$ & - & 0.3 & $\ldots$ \\
\hline 3 & $\begin{array}{l}\mathrm{Kx}=1.07 e+1 \\
\mathrm{Ky}=1.07 e+1 \\
\mathrm{Kz}=3.0 \mathrm{e}-2\end{array}$ & $1.0 e-2$ & - & 0.3 & $\cdots$ \\
\hline
\end{tabular}

\section{MODEL CALIBRATION}

Steady-state calibration of the flow model was accomplished by adjusting recharge and hydraulic conductivity values until the simulated head values closely matched measured target values. Target values were defined for 39 wells in the model area based on the mean water level, measured monthly from $4 / 91$ to $8 / 97$. The maximum water level range over this time period is $5 \mathrm{~m}(16.3 \mathrm{ft})$, occurring in the water table aquifer, and the standard deviation of all target values is $0.8 \mathrm{~m}(2.5 \mathrm{ft})$. The calibration target criteria was to achieve a ratio of the standard deviation to the target value range of less than $\mathbf{0 . 5}$ for all targets. Low ratios generally indicate that the residual errors do not significantly influence the overall model response (Anderson (1992)). In addition to quantitative calibration, target residuals show a random distribution (see Figure 4). Calibration statistics are summarized in Table II. 
Table II. Calibration statistics for target residuals.

\begin{tabular}{lccc}
\hline & $\begin{array}{c}\text { UTR } \\
\text { Aquifer }\end{array}$ & $\begin{array}{c}\text { Gordon } \\
\text { Aquifer }\end{array}$ & $\begin{array}{c}\text { Entire } \\
\text { System }\end{array}$ \\
\hline Residual Mean (m) & 1.78 & -0.015 & 1.12 \\
\hline $\begin{array}{l}\text { Absolute Residual } \\
\text { Mean (m) }\end{array}$ & 2.12 & 0.36 & 1.48 \\
\hline Standard Deviation (m) & 1.75 & 0.56 & 1.67 \\
\hline Sum of Squares (m) & 490 & 14.5 & 504 \\
\hline Min. Residual (m) & -2.3 & -0.67 & -2.3 \\
\hline Max. Residual (m) & 4.2 & 1.7 & 4.3 \\
\hline
\end{tabular}

Model calibration resulted in an average recharge of $0.23 \mathrm{~m} / \mathrm{yr}(9 \mathrm{in} / \mathrm{yr})$ for the system. Aadland et. al. (1995) reported a range of recharge values between $0.23 \mathrm{~m} / \mathrm{yr}$ to $0.4 \mathrm{~m} / \mathrm{yr}$ (6 and $16 \mathrm{in} / \mathrm{yr}$ ) depending upon the vegetation cover, with evapotranspiration much higher in the heavily forested areas. Since the preferred site is currently a forested area, the $.023 \mathrm{~m} / \mathrm{yr}(9 \mathrm{in} / \mathrm{yr})$ recharge rate is probably near the true value; however, it is

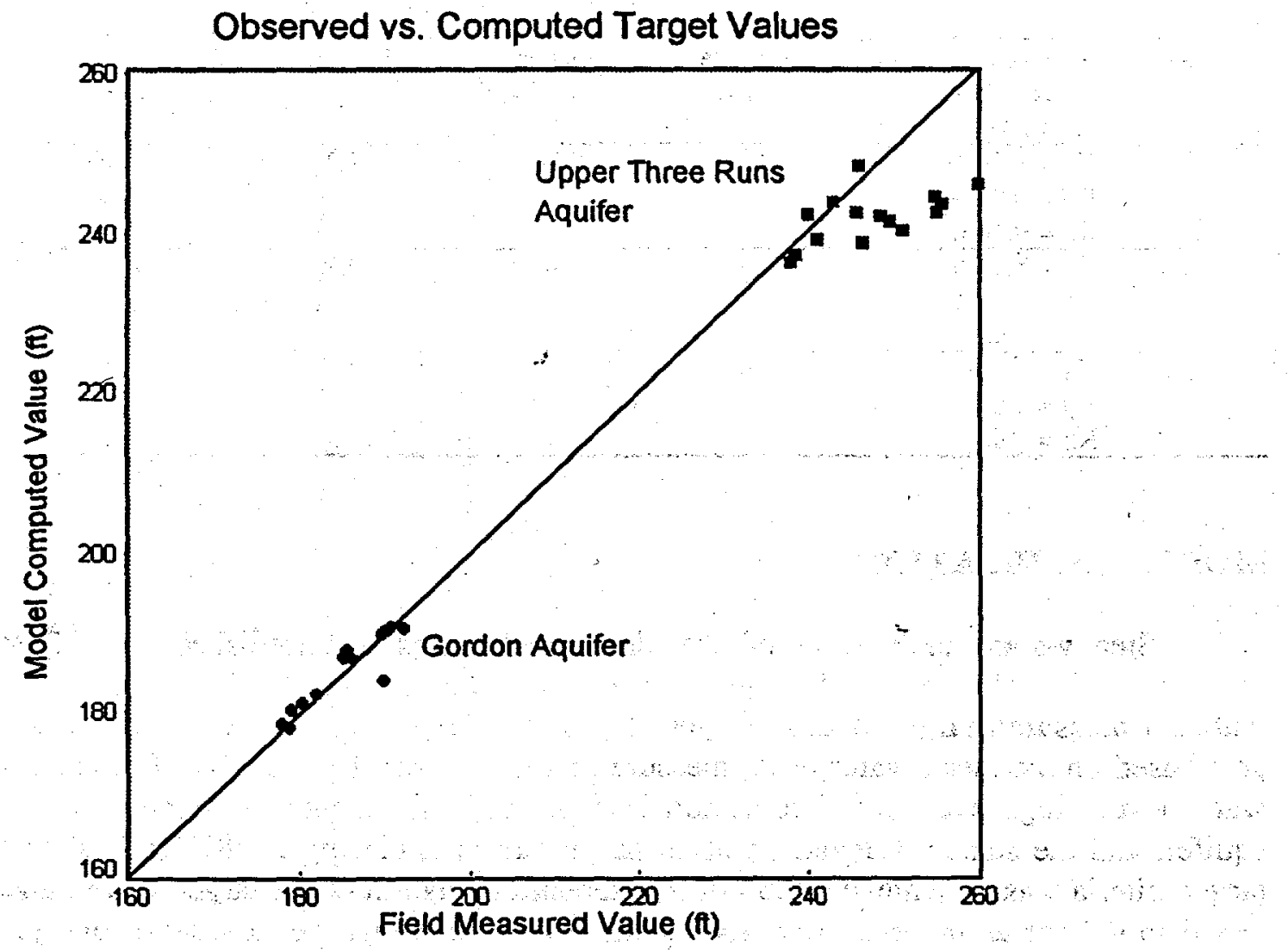

Figure 4 Measured head versus model calculated head for calibration targets. 


$$
\text { WSRC-TR-99-00373 }
$$

realized that construction of the facility will result in the area being cleared and likely result in a slight increase in recharge. In a previous study of the model area, (Thibault (1996)) performed a sensitivity study of the effects of increased recharge on the travel time and found a reduction of about 54 percent when the upper bound of $0.4 \mathrm{~m} / \mathrm{yr}$ (16 in/yr) was used. .

Model calibrated values of horizontal and vertical hydraulic conductivity are; 0.91 and $0.09 \mathrm{~m} /$ day ( 3 and $0.3 \mathrm{ft} /$ day) for the Upper Three Runs Aquifer, 4.5e-5 and $4.5 \mathrm{e}-5$ $\mathrm{m} /$ day (1.5e-4 and 1.5e-4 ft/day) for the Gordon Confining Unit, and 10.7 and 0.03 $\mathrm{m} /$ day ( 35 and $0.1 \mathrm{ft} /$ day) for the Gordon Aquifer, respectively. These values are similar to those reported in the literature for the hydrogeologic units simulated. Table III shows the relationship between initial input conductivity and final calibration conductivity.

Table III. Initial and calibration hydraulic conductivity for the flow model

\begin{tabular}{lccc}
\hline & $\begin{array}{c}\text { UTR } \\
\text { Aquifer }\end{array}$ & $\begin{array}{c}\text { Gordon } \\
\text { Confining Unit }\end{array}$ & $\begin{array}{c}\text { Gordon } \\
\text { Aquifer }\end{array}$ \\
\hline Initial Conductivity (m/day) & 1.2 & $3.9 \mathrm{e}-5$ & 9.1 \\
\hline Calibrated Conductivity (m/day) & 0.91 & $4.5 \mathrm{e}-5$ & 10.7 \\
\hline
\end{tabular}

\section{RESULTS}

\section{FLOW}

The simulations indicate flow in the Upper Three Runs Aquifer generally follows the topography. The modeled ground-water divide tends to mimic the surface water drainage divide. The model also shows a substantial downward component to flow within the Upper Three Runs Aquifer. Flow in the Gordon Aquifer is primarily northwest discharging to Tinker Creek. Based on particle tracking, non-reactive particles released to the water table in the vicinity of the APT footprint travel to the northwest discharging to Tinker Creek just east of the confluence with McQueen Branch and also discharging to Upper Three Runs. Travel times derived from particle tracking from the APT to discharge ranged from 80 to 175 years, depending on the location within the APT Target Blanket Building (Figures 5 and 6).

To estimate the effect of the uncertainty of the calibrated hydrogeologic properties on travel time, sensitivity simulations were run using increased recharge and increased horizontal hydraulic conductivity for the Upper Three Runs Aquifer and also using decreased effective porosity. The model indicates that travel times are fairly sensitive to decreases in effective porosity and are less sensitive to changes in both hydraulic conductivity and recharge. Based on current conditions and the data used for this study, a non-reactive particle released to the water table in the area of the APT footprint is estimated to arrive at a point of surface discharge in 50 to 80 years. A range of travel time is necessary due to the uncertainty in the numerical representation resulting from the limited data available. 


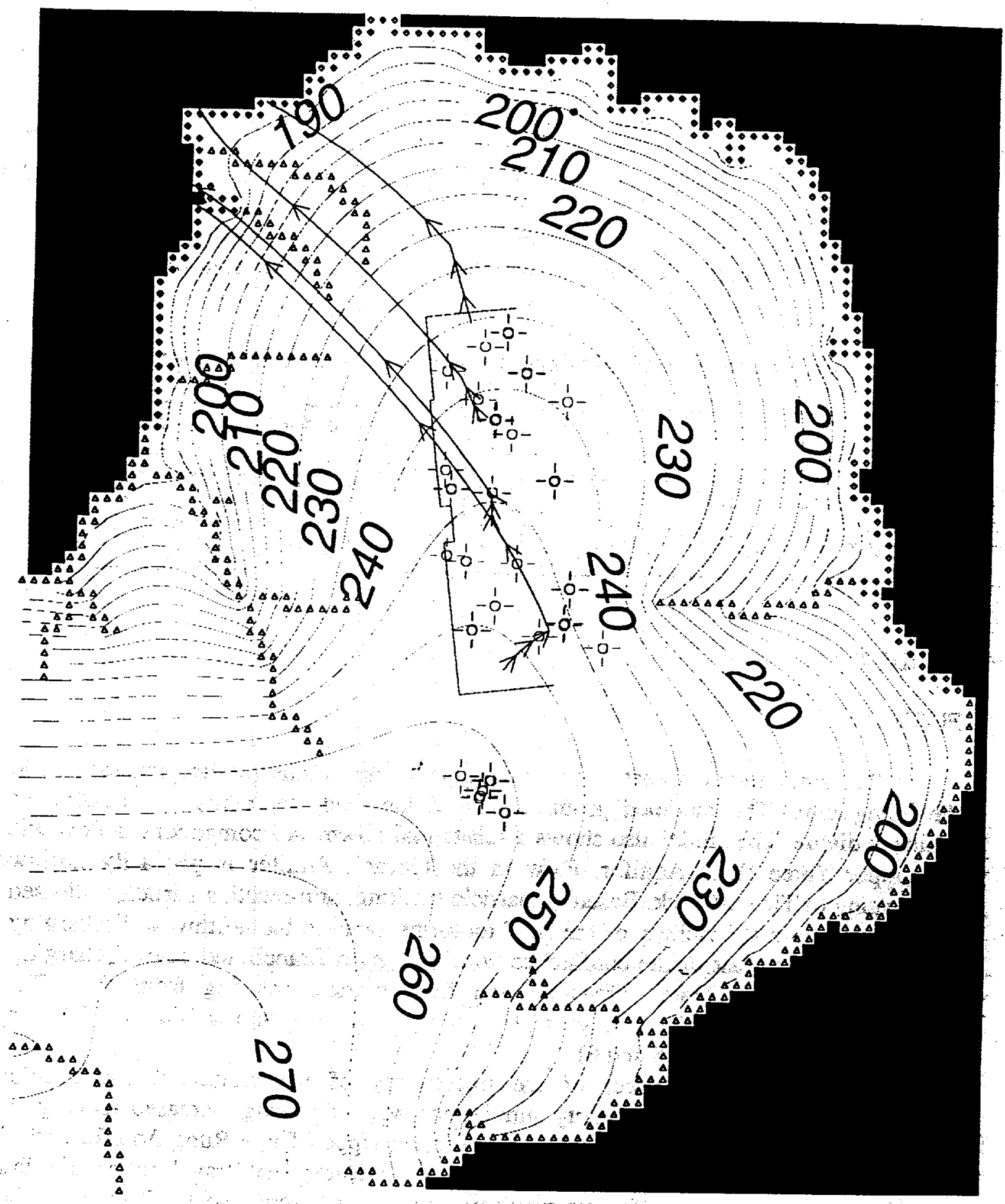

Figure 5 Upper Three Runs simulated water table and flow paths. Time mark arrows posted every 25 years. Contour interval is 5 feet. 


$$
\text { WSRC-TR-99- } 80373
$$

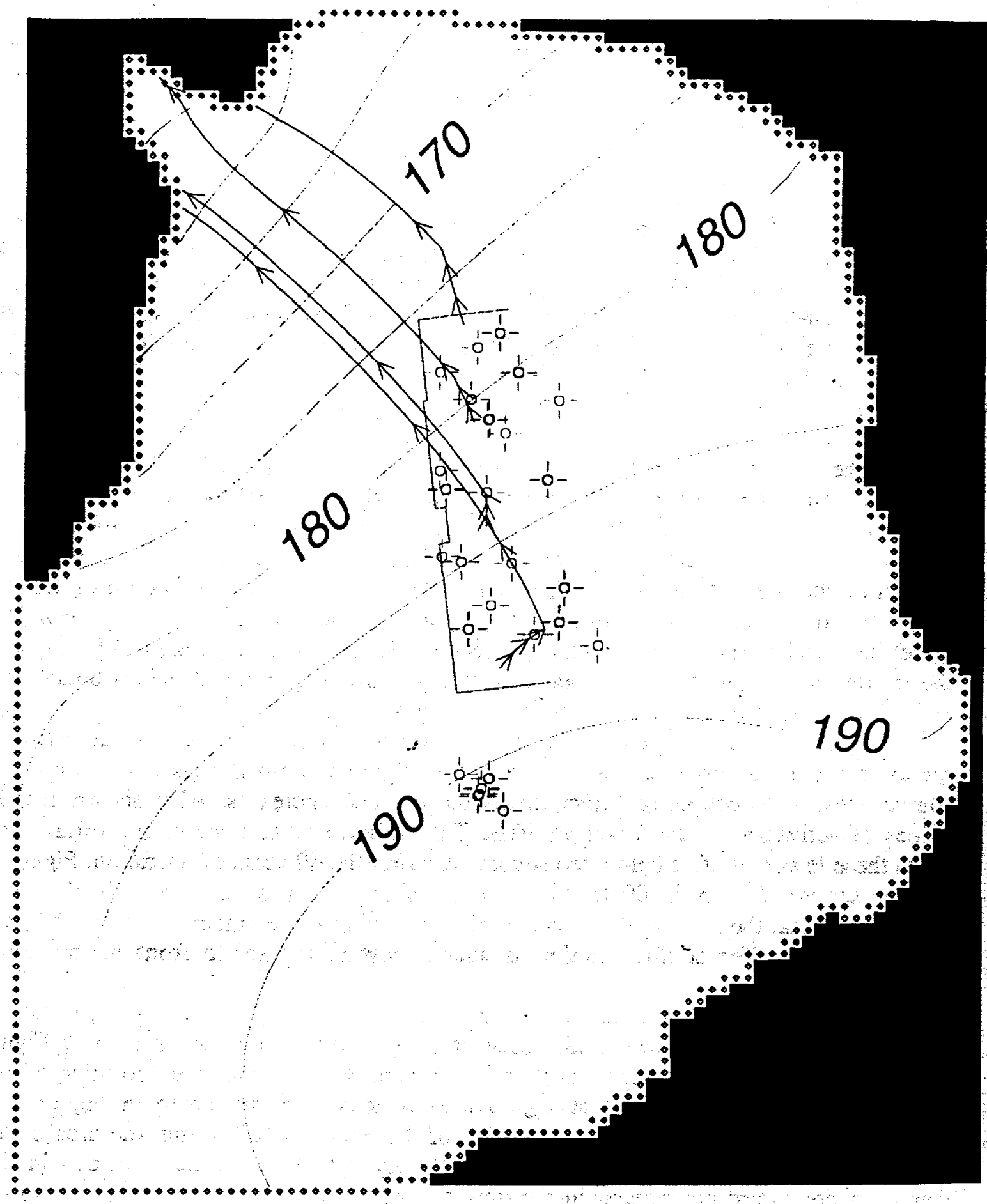

Figure 6 Gordon Aquifer simulated potentiometric map and flow paths. Time mark arrows posted every 25 years. Contour interval is 5 feet. 


\section{TRANSPORT}

In the transport modeling phase, the source release was represented as a unit recharge to the water table. This was assumed to occur only in the grid block located at the proposed location of the target blanket building. It is realized that this area will be an order of magnitude larger than the actual facility. Advective transport with no decay was used in the model. MODFLOWT ran the flow portion in steady-state for a time period of 40 years using the parameters from the flow modeling study. It then performed the transport using one year time steps for $\mathbf{4 0}$ years. The model indicates that if the source is removed after the 40-year time period the activation will only decline. Because a constant mass of tritium is being added to the system at the water table, the activation beneath the target blanket building appears to remain high even after the 40 years. On the other hand, the model shows very low concentrations of tritium down gradient. This is likely the result of the tritium mass being diluted and dispersed by uncontaminated residual groundwater and recharge moving through the system. The transport modeling indicates that after only $\mathbf{4 0}$ years the tritium has not reached the streams. This is similar to the particle tracking results.

The maximum calculated tritium activation was $1.56 \times 10^{4} \mathrm{pCi} / 1$ in the grid block which contained the source. The concentration quickly decreased to a value of $1.15 \times 10^{4}$ $\mathrm{pCi} /$ within the next grid block which represented a simulated monitoring well (well \#1) located at the edge of the target blanket building. The next simulated well (well \#2), located down gradient $75 \mathrm{~m}$ ( $246 \mathrm{ft}$.) from the first, had a tritium activation of $1.0 \times 10^{4}$

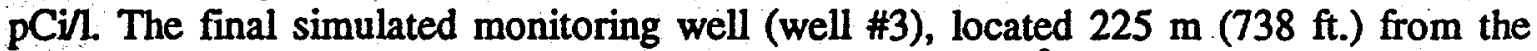
target blanket building, had a modeled activation of $5.0 \times 10^{3} \mathrm{pCi} /$. Figure 7 is a plot of the tritium activation at the modeled monitoring wells. All modeled values outside the area of the facility are below the drinking water standard of $2.0 \times 10^{4} \mathrm{pCi} /$.

Figure 8 is a plot of the activation across the modeled domain in an east-west section through the target blanket building. This figure shows the peak activation at the source area, and decreasing activation as the distance increases. Also shown are the values of activation in the lower aquifers. This indicates that some of the tritium will reach these lower aquifers below the source area after the 40 years of operation. Figure 9, another section $732 \mathrm{~m}(2400 \mathrm{ft})$ to the north, shows the reduction in activation with distance and that the mass in the lower aquifer is moving at the higher velocity. The peak in the lower aquifer at this position is almost beyond the solute front in the upper aquifers.

The simulated future tritium activation levels following 40 years of operation at the facility within the upper aquifer zone and the confining unit are shown in Figure $10 \mathrm{a}, \mathrm{b}$. The plume in the upper aquifer has moved well beyond the footprint of the proposed facility, although not at high levels of activation, as shown in Figure 10a. Within the confining unit, the major portion of the plume is still within the area of the footprint as shown in Figure 10b. This figure closely follows the particle tracking in that there is a northward component in the upper aquifer and confining layer. In the lower aquifer (Figure 11), the tritium plume has moved significantly beyond the footprint but a large portion of the plume is below an activation level of $1 \times 10^{3} \mathrm{pCi} /$. Here the plume also agrees with the particle tracking in that the flow in the lower aquifer is moving toward the northwest. 


$$
\text { WSRC - TR-99-00373 }
$$

To simulate a possible limiting condition, a simulation was run in which the tritium activation at the source was increased to $2.00 \times 10^{5} \mathrm{pCi} /$ for the 40 year time period. In this case the peak concentration at the edge of the target blanket building at 40 years was modeled as $3.4 \times 10^{4} \mathrm{pCi} /$, which exceeds drinking water standards. The results for this simulation within the two aquifers and the confining unit are presented in Figure 12. The plume areas are larger for this case compared to the previous modeled source term as one would expect. However, the plume has not yet reached the on site streams after 40 years. At all other wells used as model monitoring wells, the concentrations were below the drinking water standard.

As a check, an analytical solution was also calculated in which both decay and dispersion were included (see Appendix 1). This result indicated that the concentration in the model monitoring well located at the exterior wall of the target blanket building would be below the drinking water standard even for the case of the large source term.

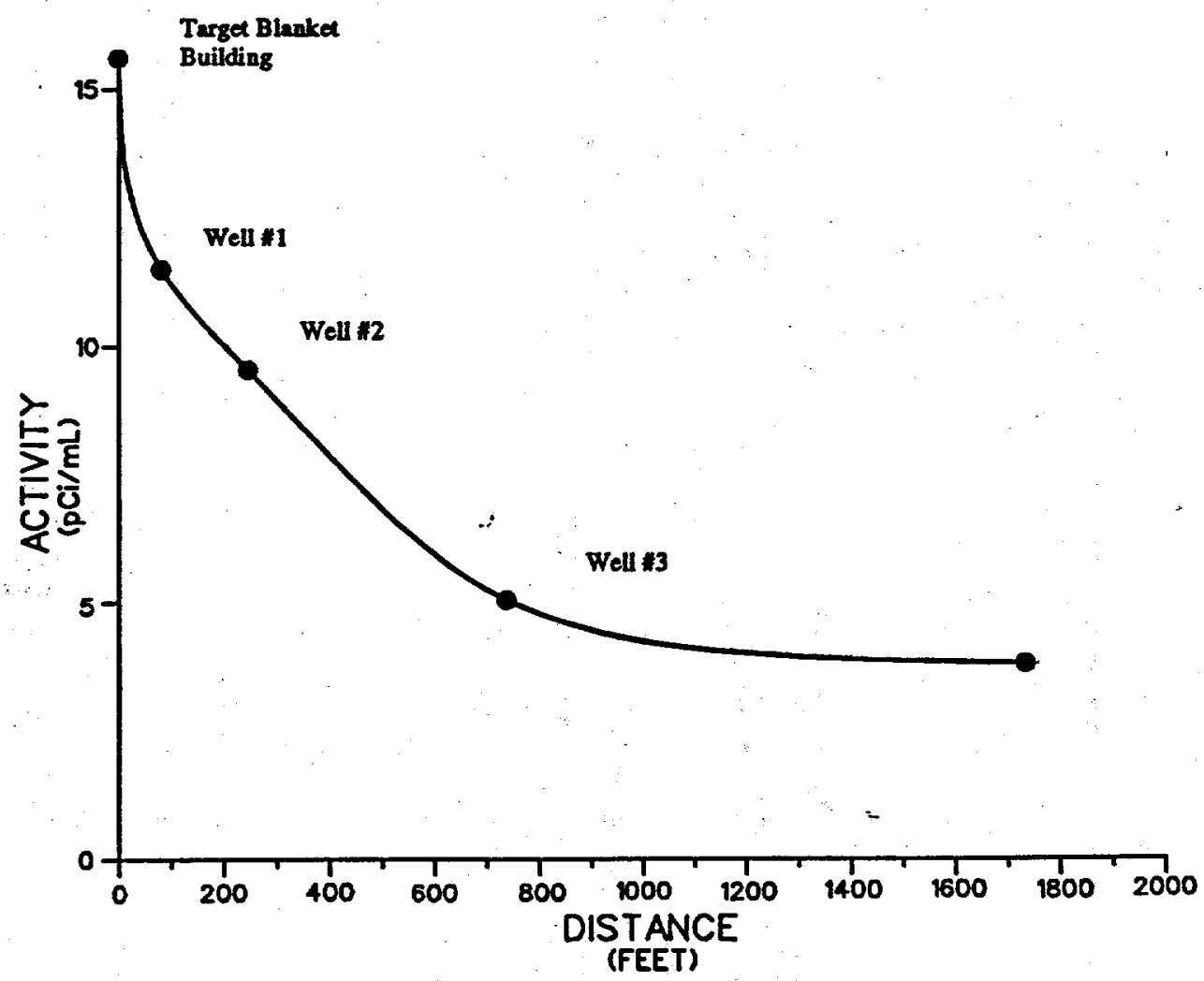

TRITIUM CONCENTRATIONS AT MODELED MONITORING WELLS

Figure 7. Tritium concentration at modeled monitoring wells located downgradient of the Target Blanket Building. 


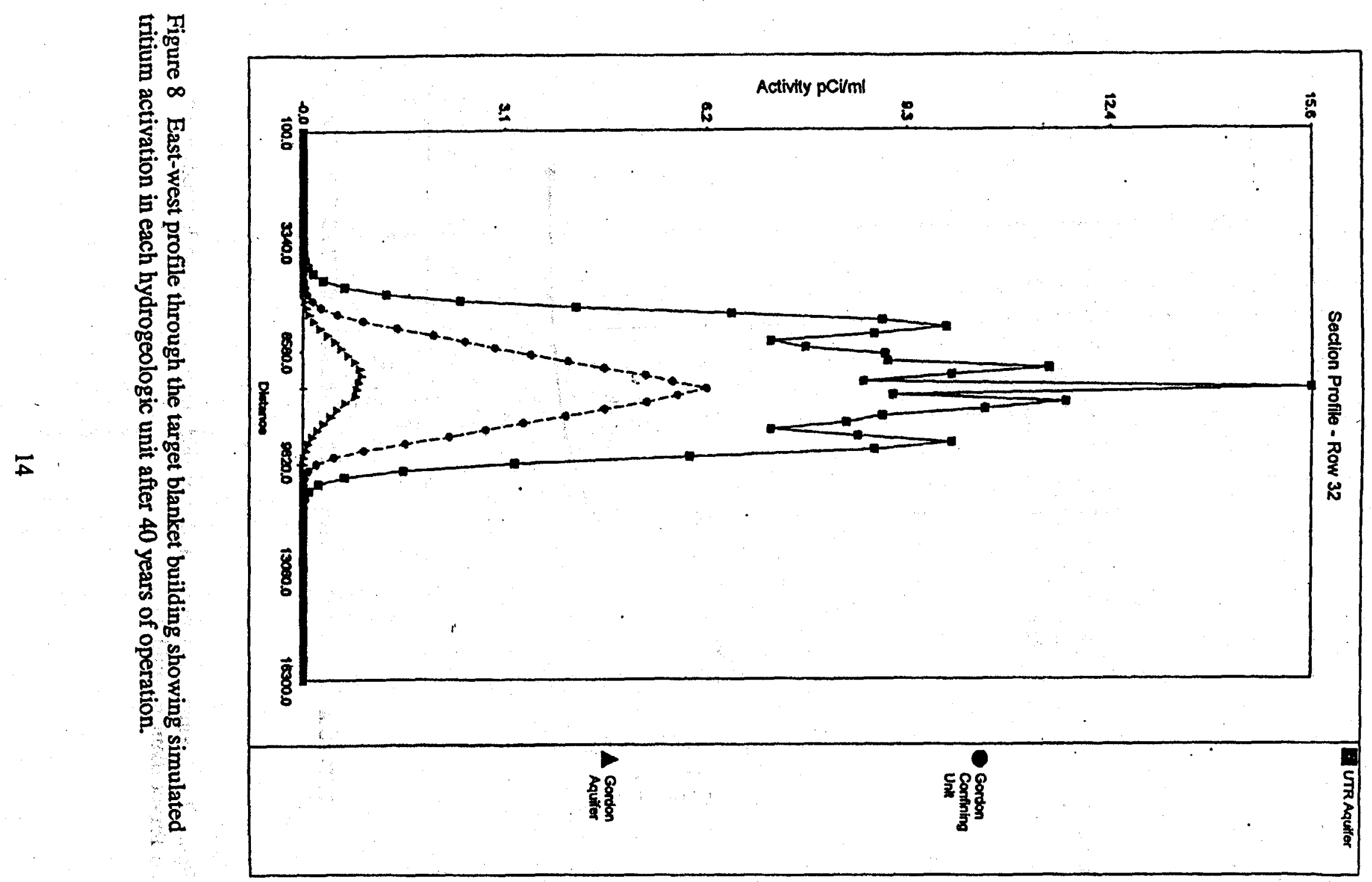




$$
\text { WSRC-TR-99-00373 }
$$

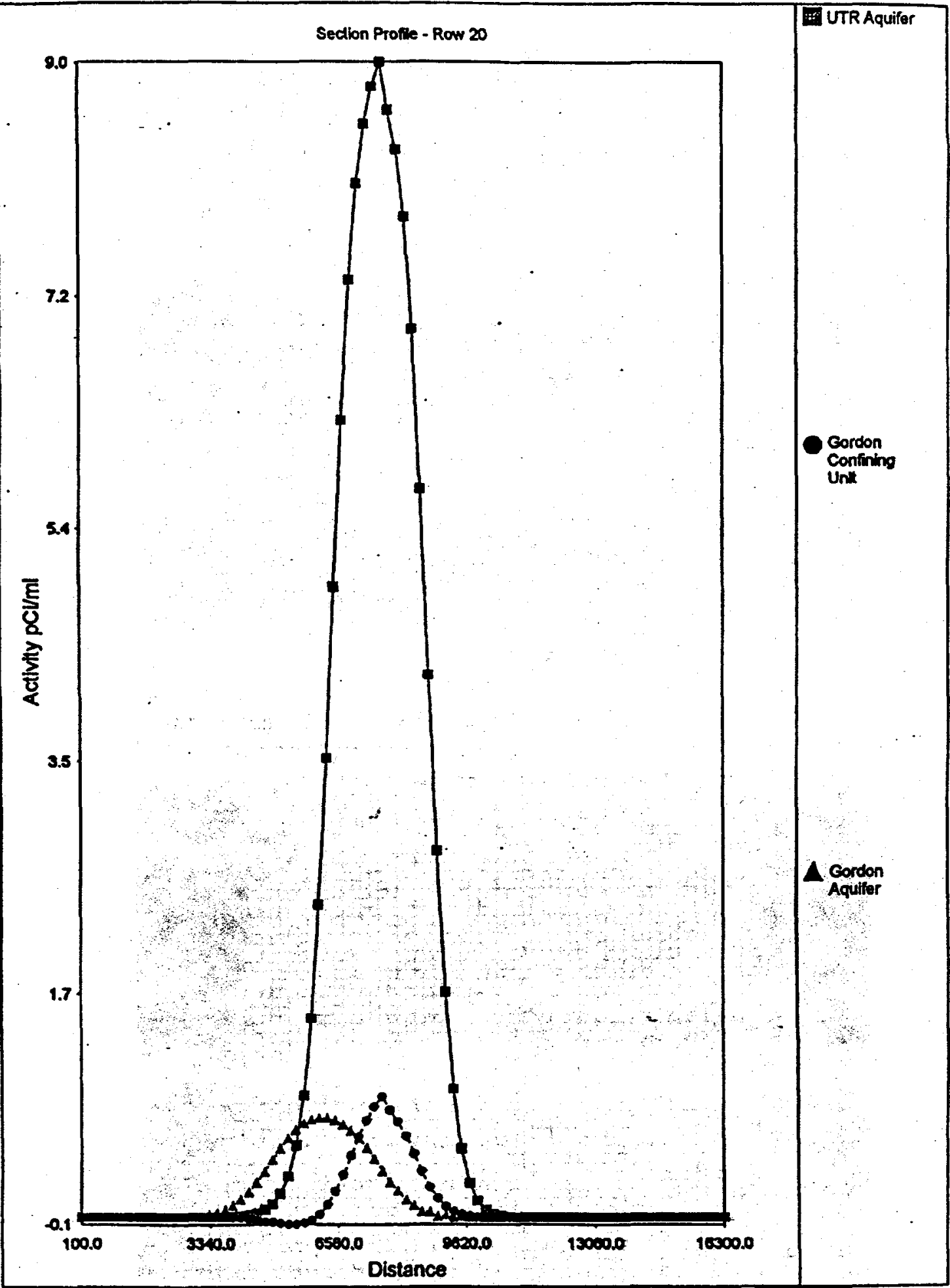

Figure 9 East-west profile 732 meters north of the target building showing simulated tritium activation in each hydrogeologic unit after $\mathbf{4 0}$ years of operation. 
20

40

60

80

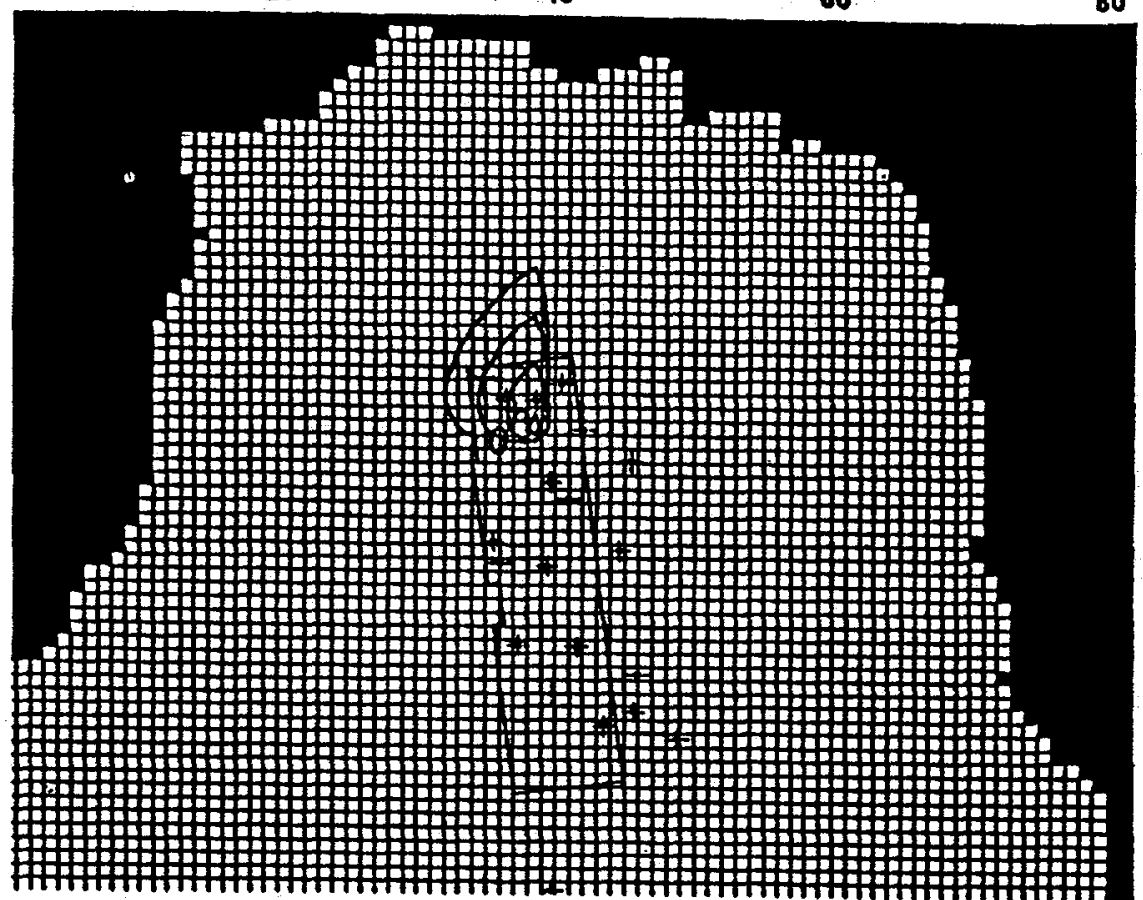

Figure 10a Upper Three Runs Aquifer

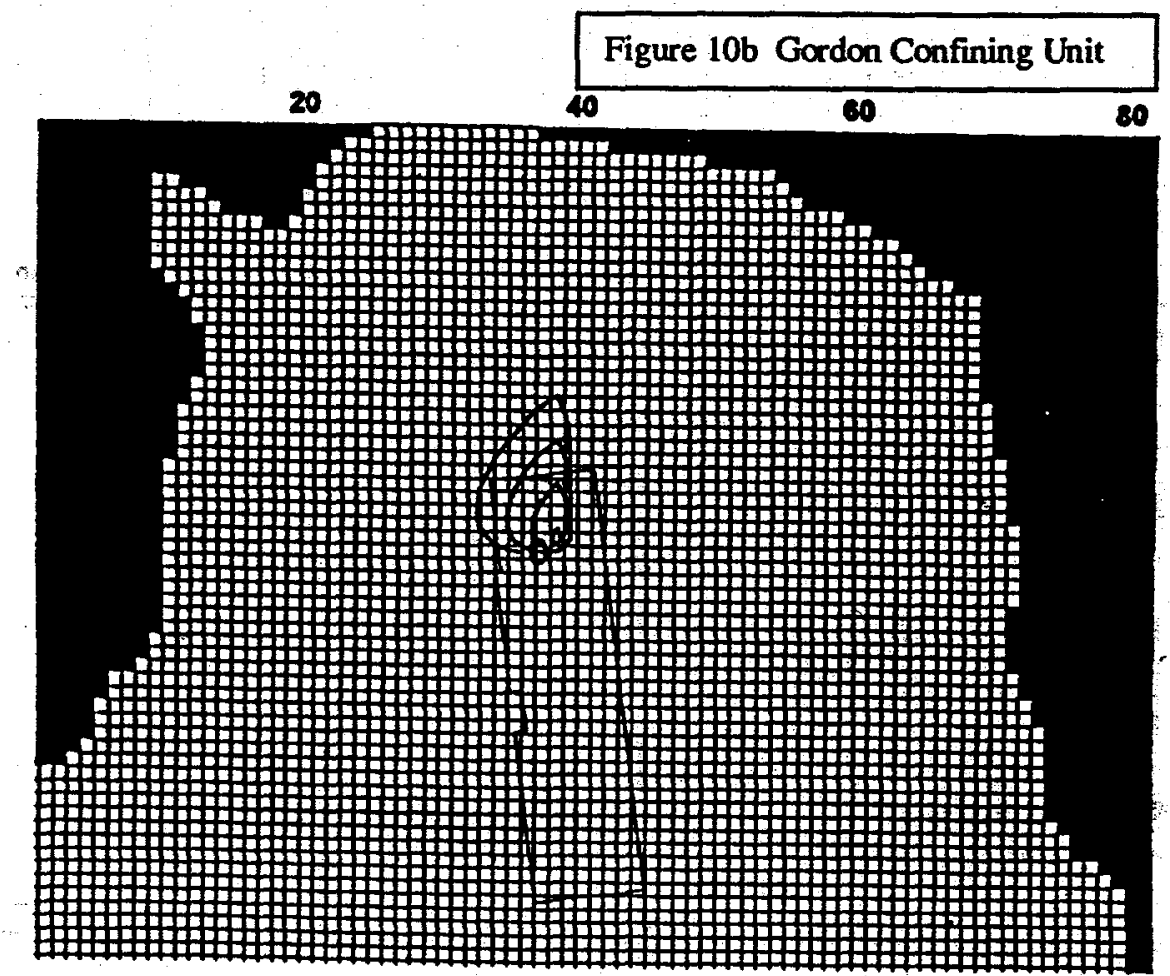

Figure 10a, 10b Simulated extent of future tritium activation after 40 years of operation based on an activation source of $1.56 \mathrm{e}+4 \mathrm{pCi} / \mathrm{l}$, Upper Three Runs Aquifer and Gordon Confining Unit.. 


$$
\text { WSRC-TR-99-00373 }
$$

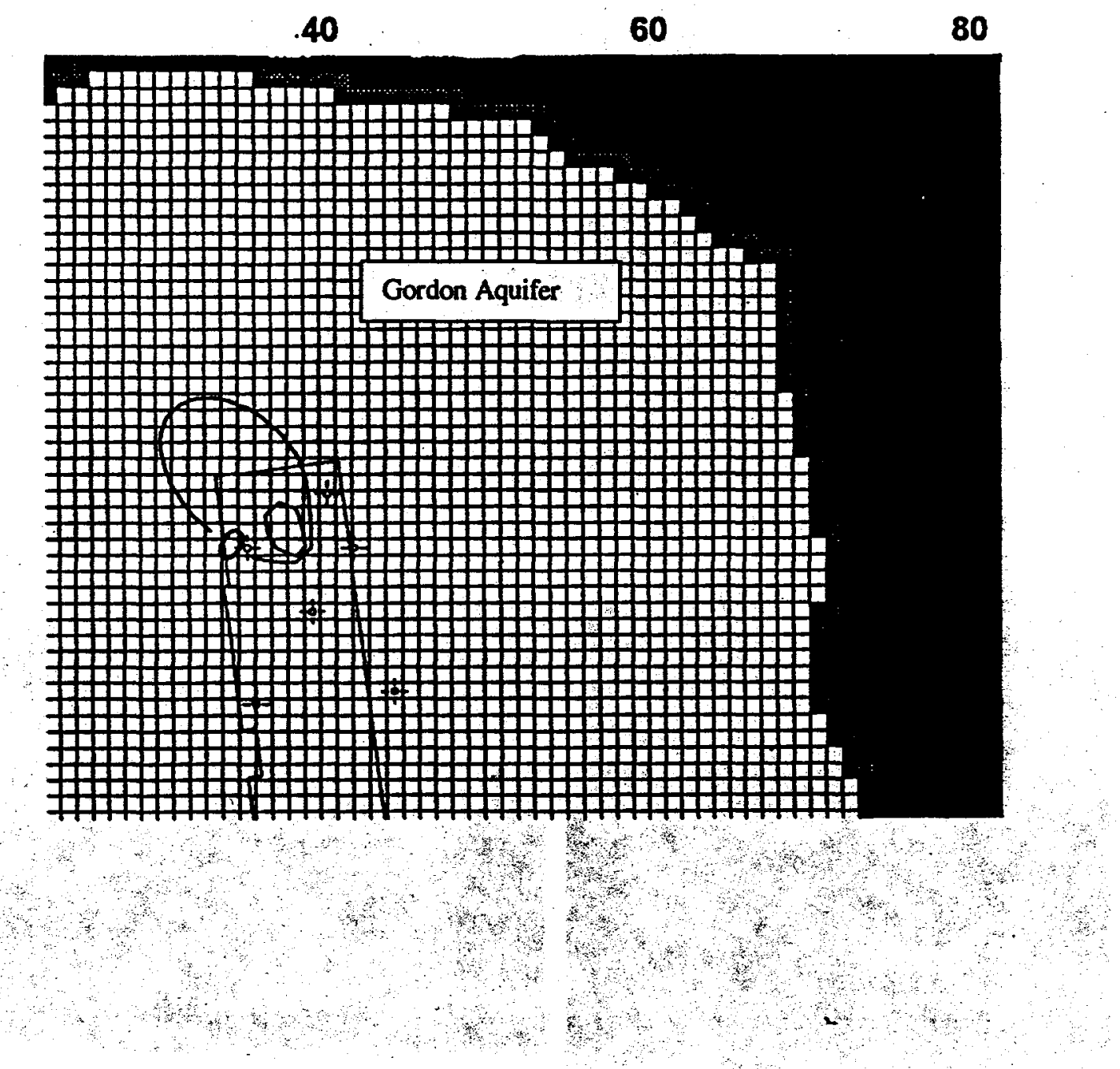

Figure 11 Simulated extent of future tritium activation after 40 years of operation based on an activation source of $1.56 \mathrm{e}+4 \mathrm{pCi} / 1$, Gordon Aquifer. 


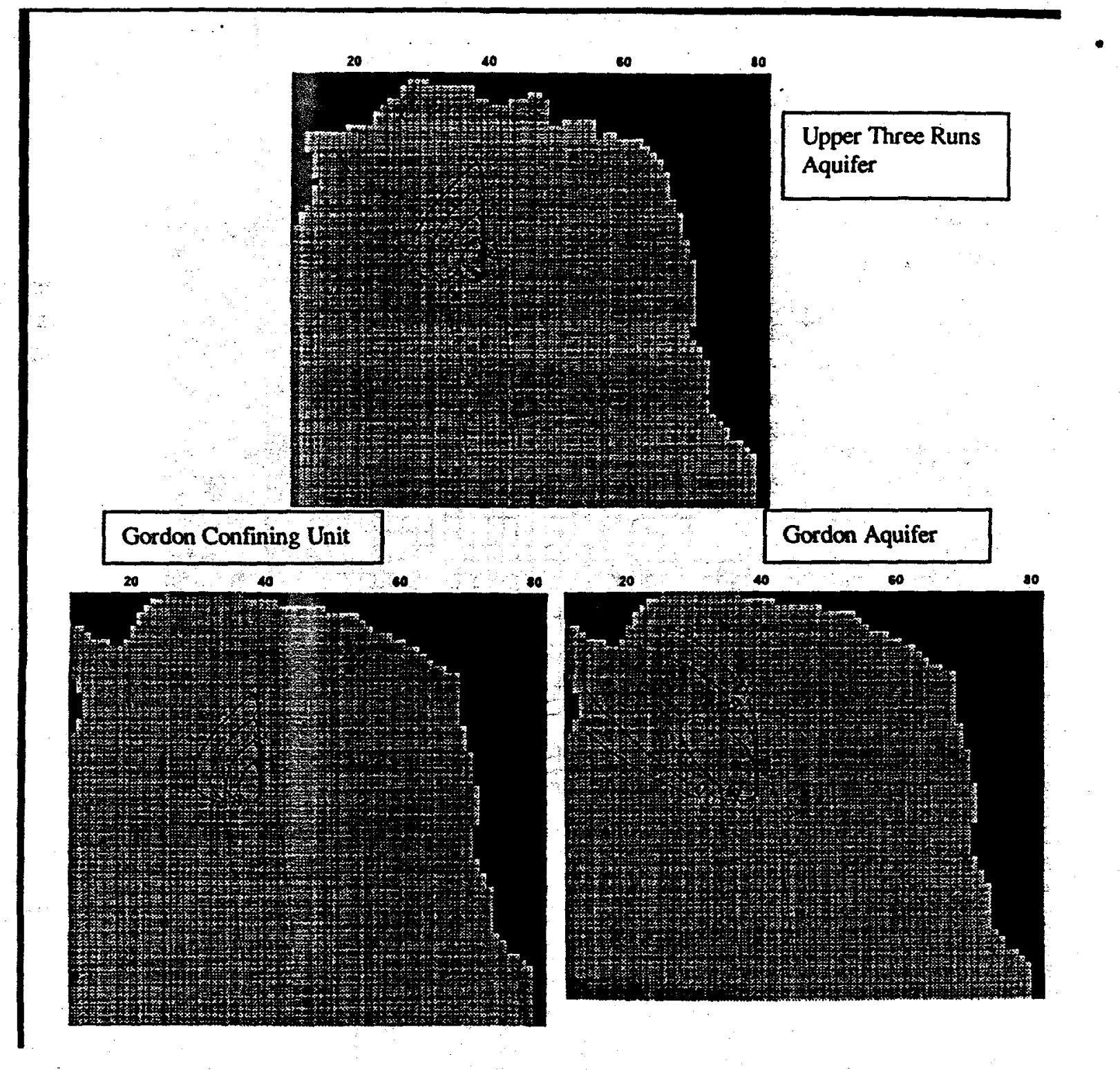

Figure 12 Simulated extent of future tritium activation after 40 years of operation based on an increased activation source of $2.0 \mathrm{e}+5 \mathrm{pCi} / \mathrm{l}$. 


\section{CONCLUSIONS}

$$
\text { WSRC-TR-99-00373 }
$$

The results of the ground-water modeling provide a representation of the groundwater flow directions and velocities in the vicinity of the proposed APT facility that are in agreement with the limited data available. Limitations of this model result from the lack of spatially distributed data within the ground-water divide which make it more difficult to accurately represent the hydrogeologic system. Calibration of the model is limited to the central region where calibration target data is available. Additional geologic and hydrogeologic data such as: hydraulic conductivity measurements, water levels, stream flow, location of seeps and their volume, and geologic data on the distribution of clays within the upper portion of the geologic column, will help refine the understanding of the system.

A large uncertainty exists in the predictions provided by this modeling since the variability of the hydrogeologic and transport parameters are unknown and therefore are difficult to account for in the model. It is known from the detailed site characterization performed to date that the proposed site is underlain by a complex series of sandy clays and clayey sands which vary spatially. Also the values of hydraulic conductivity used in the analysis are from a limited number of pumping tests confined to the southern portion of the modeled area and in the general region surrounding the site. Therefore, predictions of tritium velocity and spreading in the region of the APT Target Blanket Building are subject to a high degree of uncertainty, which we are unable to quantify better than the 50-80 years calculated by the model

The ground-water flow and solute transport numerical modeling to simulate future concentrations of tritium at the proposed APT site has shown that plumes of low but detectable tritium concentrations will be produced by activation below the target blanket building. Simulations predict that some tritium will reach the Gordon aquifer at low levels. Overall, the results indicate that it is unlikely that tritium will be discharged to SRS surface streams during the proposed operating life of the facility; however, with time very low levels of tritium may reach the surface streams. The transport modeling results represent a simulation of the worst-case conditions with a continuous source and no decay occurring. These simulations are conservative by nature and actual conditions should present less potential for impact to groundwater at the proposed APT site. 


\section{REFERENCES}

Aadland, R. K., J. A. Gellici, and P. A. Thayer, (1995), Hydrogeologic Framework of West Central South Carolina, State of South Carolina Department of Water Resources, v, 5, Columbia, SC.

Anderson, M. P. and Woessner, W. W., (1992), Applied Groundwater Modeling: Simulation of Flow and Advective Transport, Academic Press, Inc., San Diego, CA.

Bear, J., (1979), Hydraulics of Ground Water, McGraw-Hill, New York.

Duffield, G. M., Benegar, J. J., and Ward, D. S., (1997), MODFLOWT, a Modular Three Dimensional Groundwater Flow and Transport Model, Hydrosolve, Inc., Reston, VA.

Fallaw, W. C., and V. Price, Jr., (1995), Stratigraphy of the Savannah River Site and Vicinity, Southeastern Geology, v. 35, p. 21-58.

Hiergesell, R. A., (1995), A Regional Water Table Map of the Savannah River Site, 1Q-5, WSRC-MS-95-0524, Westinghouse Savannah River Company, Aiken, SC.

McDonald, M. G. and A. W. Harbaugh, (1988), A Modular Three-dimensional Finite Difference Ground Water Flow Model, Techniques of Water Resources Investigations of the U. S. Geological Survey, Book 6, Washington, D. C.

Ogata, A, and Banks, R. B., (1961), A Solution of the Differential Equation of Longitudinal Dispersion in Porous Media, U. S. Geological Survey Professional Paper 411-A, U. S. Government Printing Office, Washington, D.C.

Prowell, D. C., (1996), Preliminary Geologic Map of the Savannah River Site, Aiken, Allendale, and Barnwell Counties, South Carolina, Open-File Report 94-181, U.S. Geological Survey, Atlanta, GA.

Rumbaugh III, J. O., (1995), Groundwater Vistas, Advanced Model Design and Analysis for Windows, Environmental Simulations, Inc. Herndon, VA.

Thibault, J. J., (1996), Numerical Model of the McQueen Branch-Mill Creek Divide, Savannah River Site, South Carolina: Characterization of Ground-Water Flow in Tertiary Sand Aquifers, M. S. Thesis presented to the Graduate School of Clemson University, Clemson, SC.

Thibault, J. J. and Stephenson, D. E., (1998), Groundwater Flow Modeling at Proposed APT Site Number 2, PECD-SGS-97-0250, Westinghouse Savannah River Company, Aiken, SC. 


$$
\text { WSRC-TR-99-00373 }
$$

\section{APPENDLX 1}

To estimate the size of the source required to produce a tritium concentration equal to one-half the drinking water standard in a potential compliance well located at the wall of the Target Blanket Building an analytical solution was used. The Ogata-Banks (1961) equation in one-dimension as developed by Bear (1979) for transport involving first-order kinetics is:

$C=\left(\frac{C_{0}}{2}\right) \exp \left\{\left(\frac{x}{2 \alpha_{x}}\right)\left[1-\left(1+\frac{4 \lambda \alpha_{x}}{v}\right)^{\frac{1}{2}}\right]\right\} \operatorname{erfc}\left[2 \frac{x-v t\left(1+4 \lambda \alpha_{x} x / v\right)^{\frac{1}{2}}}{2\left(\alpha_{x} v t\right)^{\frac{1}{2}}}\right]$

where $\quad C_{0}=$ original concentration

$x=$ distance (i.e. to the well)

$\alpha_{x}=$ dispersivity

$\lambda=$ disintegration constant or $\ln 2 /$ half-life

$v=$ velocity (for unretarded contaminant the velocity of the water)

When the argument of the error function term approaches -2 the above equation reflects a steady-state condition. The dispersivity used was 3 meters, the distance was 100 meters, and the disintegration constant was 1.79E-9. One-half the drinking water standard was taken as $10,000 \mathrm{pCi} /$. 